Ritchie, W. A., 1953 - A probable PaleoIndian site in Vermont. American Antiquity, $18: 249-258$.

Roberts, F. H. H., 1943 - "A New Site." In Nates and News. - American Antiquity, $8: 300$.

1951 - The Early Americans. Scientific American, 184:15-19.

1957 - Personal communication.
Wettlaufer, B. N., 1951 - An archaeological survey of Saskatchewan, no. 1. The National Museum of Canada and Provincial Museum of Saskatchewan. $150 \mathrm{pp}$. plus appendix. Unpublished.

1958-The Long Creek Site. (manuscript)

WoRMINGTON, H. :M., 1957 - Ancient Man in North America. Denver Museum of Natural History, Popular Series No. 4, 322 pp. (Fourth Ed., revised). Denver.

\title{
The Spadefoot Toad in Saskatchewan
}

By R. W. Nero, Saskatchewan Museum of Natural History, Regina

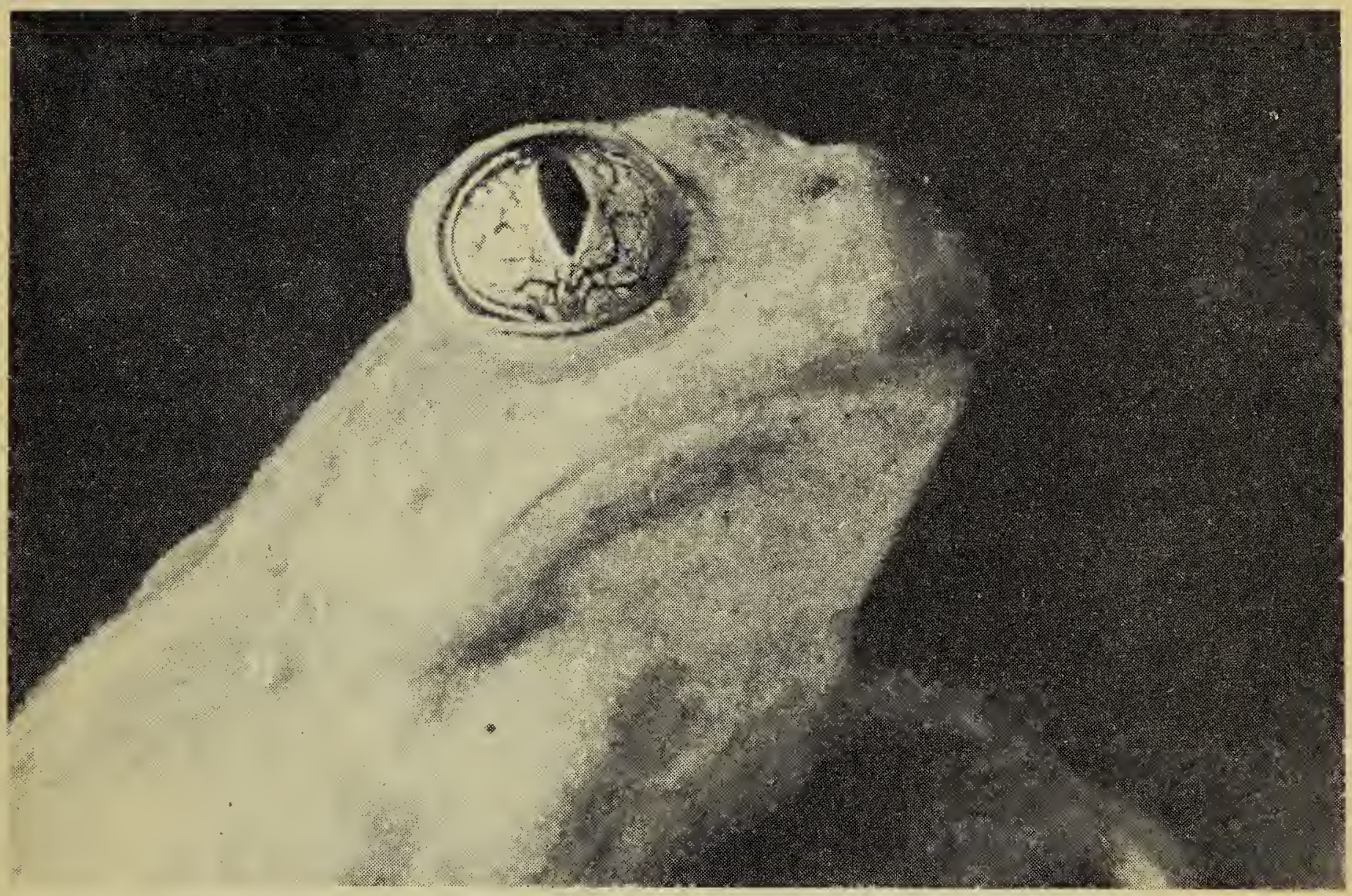

Close-up of SPADEFOOT TOAD

While collecting small mammals in the general vicinity of the South Saskatchewan River at Elbow in the summer of 1958, Fred W. Lahrman and $I$ were fortunate in finding several specimens of the Central Plains Spadefoot (Scaphiopus bombifrons Cope). This interesting toad, as its name suggests, is found throughout the central plains from Northern Mexico to Canada. R. C. Stebbins (1951. Amphibians of Western North America. University of California Press) failed to mention any Canadian records but E. B. S. Logier and G. C. Toner (1955. Checklist of the amphibians and reptiles of Canada and Alaska. Contrib. Royal Ontario Museum of Zoology and Paleontology, No. 41) list six Canadian locali-
(August, 1958). Note vertical pupil.

Photo by R. W. Fyfe ties, five in Alberta and one in Saskatchewan (see map). The Saskatchewan record was obtained by Dr. E. J. Moore at Alsask on June 25, 1951. However, the Museum has an earlier record for Saskatchewan that has not been published: what is apparently the first spadefoot for the province was collected on July 25, 1949, by Lahrman at Bengough near the Big Muddy Valley. This toad was found at night with the aid of a flashlight.

In the morning of July 14, 1958, we found a spadefoot caught in a mousetrap set overnight at the base of a large sand-hill six miles southeast of Elbow, Sask. It seems likely that it was attracted to the trap by ants and other insects feeding on the 


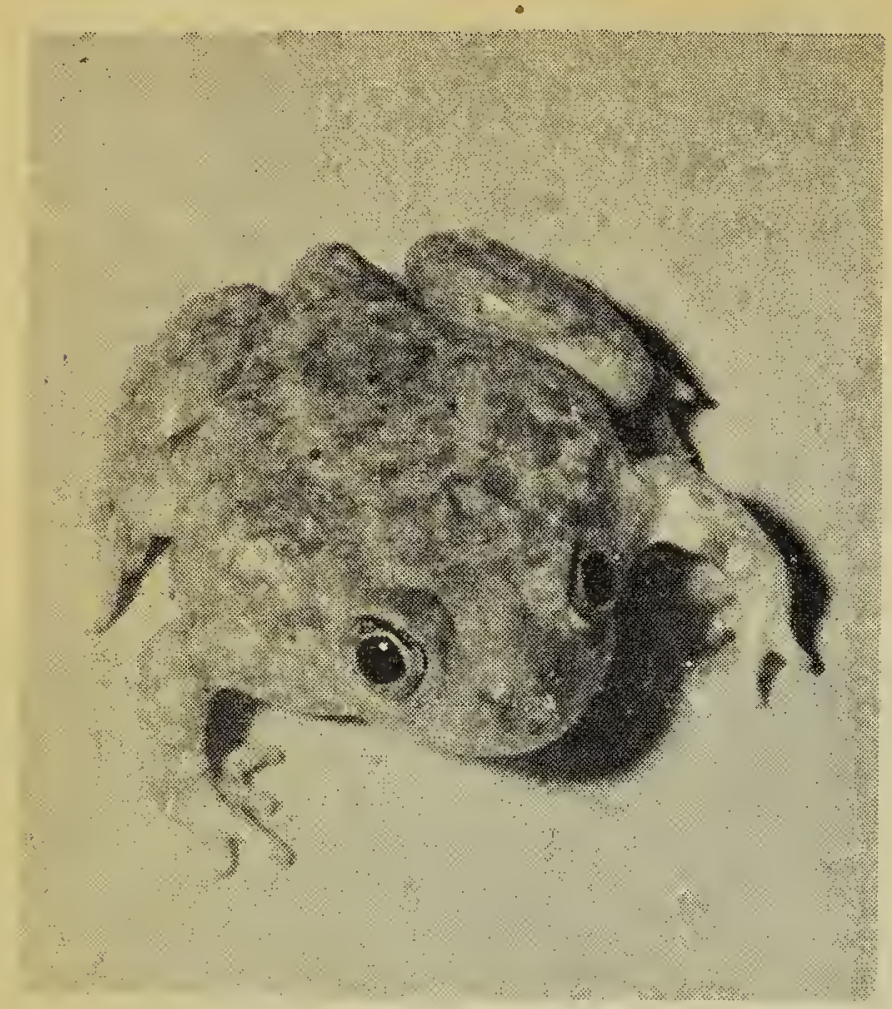

Photo by R. W. Fyfe

SPADEFOOT TOAD, August, 1958

trap bait. Later in the afternoon another toad was accidentally uncovered while we were digging for Pocket Mice on a sandy road in the same vicinity. This toad was less than one foot underground beneath a slight circular depression which we had taken to be the mouth of a closed Pocket Mouse burrow. Spadefoots normally remain underground during dry weather. They dig remarkably fast; a protuberance on their hind-leg, from which the derive their name, aids them in digging down backwards and out of sight in a few minutes. A.bout 10 p.m. on July 15 we captured two more spadefoots in the car headlights on the same road. Six others were collected the same night on a sandy road on the south side of the South Saskatchewan River, about four miles southwest of Elbow. No doubt this large number of spadefoots represented an increased activity following late summer rain. It rained heavily on the night of July 12 and lightly all afternoon and evening July 13. According to Stebbins (op. cit.) spadefoots usually appear with the rains, breeding after heavy rains in spring and summer, in temporary pools usually of considerable size. In Kansas they were observed breeding as late as Augusit 8. With this information in mind it should be possible to find spadefoots in other localities. They are easily recognized because of their unique vertical

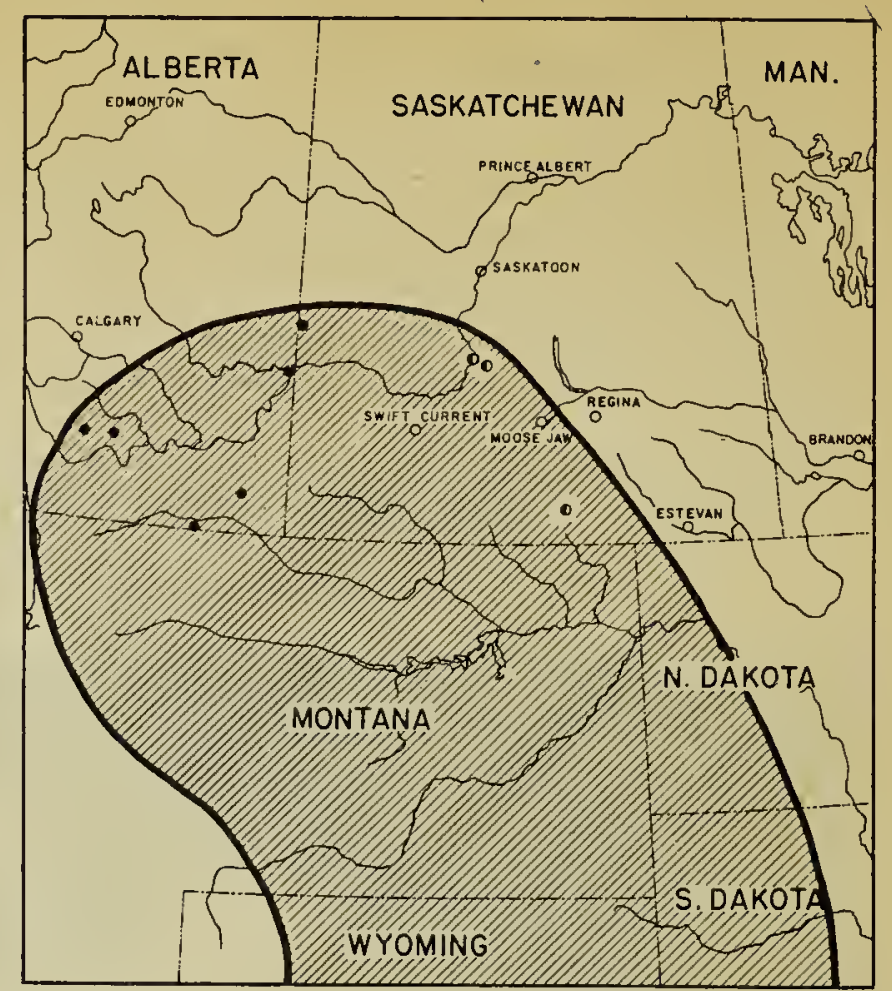

Northern distribution of the SPADEFOOT. Former records-solid circles; new recordshalf-solid circles. Map prepared by Theo. Kramer, Survey Branch, Dept. of Natural. Res.

pupils (see photo). They are pale greenish-gray and are smoother than most other toads. They are frog-like in many respects and are even rather fast-moving. Further records are certainly desirable, and we would like to hear from anyone who may be familiar with this interesting animal. The present distribution of the spadefoat (see map) provides additional evidence of the semi-arid nature of the southwestern portion of Saskatchewan, an extension of the Northern Plains. The varied fauna of this interesting region includes İangaroo Rats (Blue Jay, Dec. 1956), Pocket Mice (Blue Jay, Dec., 1958), Horned Toads (Blue Jay, Sept. 1957), Rattlesnakes (Blue Jay, March, 1956), and Prairie Dogs (Blue Jay, Sept., 1958). Further situdies in the South Saskatchewan River basin are being planned, particularly in view of the future flooding of the valley floor from Outlook west nearly to the border by a large dam which is now under construction. Anyone with information concerning this area is invited to correspond with the Museum or the Blue Jay. We would like to know about common as well as uncommon animal life, about nesting hawks, etc., about specimens which might be available from the area and any clues whatsoever to the natural history of this region. 